\title{
EVALUATIVE LANGUAGE IN SPOKEN AND SIGNED STORIES TOLD BY A DEAF CHILD WITH A COCHLEAR IMPLANT: WORDS, SIGNS OR PARALINGUISTIC EXPRESSIONS?
}

\section{Lea Nieminen and Ritva Takkinen University of Jyväskylä}

\begin{abstract}
In this paper the use and quality of the evaluative language produced by a bilingual child in a story-telling situation is analysed. The subject, an 11-year-old Finnish boy, Jimmy, is bilingual in Finnish sign language (FinSL) and spoken Finnish. He was born deaf but got a cochlear implant at the age of five. The data consist of a spoken and a signed version of "The Frog Story". The analysis shows that evaluative devices and expressions differ in the spoken and signed stories told by the child. In his Finnish story he uses mostly lexical devices - comments on a character and the character's actions as well as quoted speech occasionally combined with prosodic features. In his FinSL story he uses both lexical and paralinguistic devices in a balanced way.
\end{abstract}

Keywords: storytelling, evaluative language, language development, bilingual language acquisition, bimodal bilingual language acquisition, Finnish Sign Language

\section{Introduction}

\subsection{Narrative skills in a bilingual context}

In the current study several aspects of language development are combined, but the main focus is on the narrative skills of a bilingual child. In this research we pay particular attention to the use of evaluative expressions as part of a narrative told in Finnish and Finnish sign language by an 11-year-old boy, Jimmy. Studying the evaluative language of narratives and the use of languages that differ in their modality raises developmental, linguistic and cultural issues. 
Story telling is an important skill in everyday communication. We tell anecdotes, describe events that happened yesterday, tell stories and fairy tales, provide a narrative illustration during a lecture, write a coherent report and so forth. Thus story telling is no one particular type of communication but an important device for many kinds of human communication in different situations which manifests itself in many ways. It is therefore closely involved in cultural transmission (Strömqvist and Verhoeven 2004: 3). In addition to the fact that story-telling skills are a vital part of our communication repertoire, it has been shown that children's narrative development significantly predicts their development in literacy skills (Speece et al. 1999). Children's oral narrative production may thus reveal essential information about their academic readiness (Gutiérrez-Clellen 2002: 176).

Several studies have shown that children know the basic principles of the grammar of their native language already by the age of four years (e.g. Slobin 1985). Thus by that age they have mastered the linguistic devices which can be used in narrative functions as well. However, narrative development seems to continue into school age and even beyond. Narrative skills are not based on linguistic knowledge only, but are a combination of linguistic, cognitive and social-cognitive skills (Bamberg and Damrad-Frye 1991). It is a challenge in story telling that the basic functions and uses of linguistic forms learned during a child's early years are not enough, since on the one hand narratives require multifunctional use of forms and on the other hand multiple definition of the use of any particular form (Strömqvist and Verhoeven 2004: 4). Differences in narrative skills are not attributed to children's developmental stages alone. The fact that story-telling skills consist of a complex combination of various factors is evident from the fact that a wide range of individual variation is also found among adults (Tager-Flusberg and Sullivan 1995).

Story telling involves both an internalized narrative schema and the ability to make use of linguistic forms and devices. The narrative schema refers to knowledge of how to organize information in temporal sequences, how to structure a story so that the events constitute a plot and lead up to a resolution and, finally, how to end a story in a generalisation which relates the 
events to the current or a more universal state of affairs. These skills can also be called narrative competence. The other type of knowledge, story-telling performance, refers to the ability to make use of linguistic forms. In practice these are the ability to use bound morphology, lexical expressions and various constructions in narrative functions. These two types of knowledge represent the cognitive underpinnings and lexical knowledge required in narration. (Berman 2001.) When bilingualism and narrative development are combined the whole picture becomes more complex. In bilingual development children are confronted with two sets of linguistic input and with the task of differentiating between them. Even though it has been hypothesised that the narrative development of bilingual children is impeded in both languages, the problems do not become very serious. Instead, the two languages may help each other: the acquisition of a form with particular functions in one language may trigger the acquisition of forms with a similar function in the other language as well. Thus the languages may develop an interdependency. (Verhoeven 2004.)

The interdependency of languages does not automatically imply equivalent proficiency in narrative skills (Gutiérrez-Clellen 2002). Berman (2001) has stated that children of bilingual backgrounds must go through a proficiency continuum of four different hierarchical stages in language development to achieve native-like narrative production. The most basic level consists of the core grammatical elements, that is, simple clause structures and markers for case relations etc. The second level is mastery of lexical selection. The third level of language proficiency concerns rhetorical expressiveness and the fourth level involves appropriateness of register (Berman 2001: 422).

The purpose of this study is to investigate what kinds of evaluative expressions are used by an 11-year-old bimodally bilingual boy telling a frog story (Meier 1969) in spoken and signed language. This research is not only a cross-linguistic and cross-cultural case study but also a developmental study of skills in two different languages. 


\subsection{Referential and evaluative functions in narratives}

A narrative is very often a series of events which involves certain characters, has a given temporal order, takes place in a given environment and forms a logically coherent text. A story teller him/herself may be part of the events or may observe them as an outsider. In either case he/she has to convert what he or she sees, hears and experiences into a coherent verbal form. However, recounting the actual events and formulating them into a progressive description of a plot does not yet represent a prototype of a good story. Everyday narratives that are told are seldom if ever objective descriptions of the events. Instead, narratives are told subjectively, in a way that suits the context in which they are told, emphasising certain events and skipping others, completed by the storyteller's own comments and expressions of attitude toward some of the events and therefore conveying the story teller's interpretations of and attitudes to the events. In other words, a good story also contains references to things which are not necessarily explicitly present in the course of events. (Küntay and Nakamura 2004). Labov and Waletzky (1967) made a distinction between the two main functions of a narrative: the referential function which refers to presenting a coherent continuum of events, and the evaluative function, which refers to expressions of emotions, interpretations of the events, attitudes, causality and so forth. A story is a skilful combination of referential and evaluative expressions (Shiro 2003: 192). The division into two different functions was originally based on narratives of personal experience, but the idea of narrative and evaluative expressions can be adopted also to narratives where the story teller him/herself is not involved in the events and refers to someone else's experiences, attitudes and emotions (Bamberg and Damrad-Frye 1991).

Referential expressions are used to move the plot-line, the backbone of the story, forward. The evaluative language in a narrative has a different role. Instead of moving the plotline on, it moves the focus from the action to the narrator and his/ her interpretations. (Bamberg and Damrad-Frye 1991.) Evaluative expressions create cohesion in the story and indicate the significance of the individual events (Küntay and Nakamura 2004). They give a certain perspective to the story and therefore also a reason - that it is a moral, entertaining or poetic story, for 
example - why the story is being told in the first place (see e.g. Reilly 2001). In addition to having different points of view, narrators also have different rhetorical styles and therefore stories based on exactly the same event may be told in quite different ways. However, these differences are not only individual but also cultural. Among other things, cultural factors may influence the content of the story and the perspective the story teller takes. Also the definition of a "good" story varies from culture to culture and language to language. (On speculations of cultural effects, see Küntay and Nakamura 2004: 334-335.)

The evaluative function manifests itself in many ways. Bamberg and Damrad-Frye (1991) introduce five different categories of linguistic device that are used evaluatively: a) references to "frames of minds" (feelings and mental states, e.g. happy, sad, think, wonder), b) reported speech (direct or indirect) of characters, c) "hedges" as distancing devices (e.g. probably, looks like, kind of), d) references to negative state and actions and e) causal connectors (Bamberg and Damrad-Frye 1991: 692). However, the evaluative function can also be expressed by paralinguistic means, as Reilly (e.g. 1992) has noted, including facial expressions (e.g. a smile), different kinds of gestures which are related to a particular utterance (e.g. covering the head while talking about an attacking owl), prosodic features like pitch, length and voice quality, and finally, phonological or lexical stress. While evaluative clauses can consist exclusively of linguistic devices, they may also contain paralinguistic devices. However, evaluative function can also be expressed with paralinguistic devices alone. Since evaluative expressions are what make a series of events into a narrative, development in using different evaluative devices is essential for development in narrative skills in general. In bilingual contexts this development is particularly interesting because skills in different languages may vary significantly.

In earlier studies concerning evaluative skills the main focus has been on the various devices used at different ages, since expressions of evaluation are one way of reflecting cognitive abilities. Stories focusing on human experience may also refer to psychological motivation and mental states which explain a character's actions, and understanding of these is to some extent age dependent. The listener's needs and perspective also have to be taken into account. These kinds of considerations are connected 
to cognitive development and to theory of mind, the ability to interpret one's own and others' actions. (Tager-Flusberg and Sullivan 1995.) This study not only draws upon developmental studies, but also makes some cross-linguistic comparisons (e.g. Küntay and Nakamura 2004, comparison between Japanese and Turkish narratives).

In their age-related study on narratives Bamberg and Damrad-Frye (1991) found that adults used evaluative devices in their narratives three times as often as 5-year-olds and two and a half times as often as 9-year-olds. Of the different devices used, adults seemed to use more references to "frames of mind", that is to feelings and mental states, than children. A slight preference for "frames of mind" expressions was evident already in 9-yearolds, but the 5-year-olds used all linguistic devices equally. Also Eaton, Collins and Lewis (1999) reported that there is a clear age-related increase in the use of evaluative expressions. However, they also found that prompt questions asked by a listener lifted 5-year-olds' evaluative performance. They concluded that 5 -year-olds probably have more cognitive abilities than spontaneous story telling manages to reflect and that scaffolding may significantly change the use of evaluative expressions. The results also suggest that despite their cognitive and linguistic abilities children at this age have not yet realised the actual function of evaluative language in narration.

As we have already seen, in Reilly's studies $(1992,2001)$ evaluation in narratives is not restricted to linguistic expressions alone, but paralinguistic devices are equally taken into account as a means of expression. Reilly (1992) reported that 3-4-year-old children produced rather incoherent and interactive narratives compared to older children's stories, but they used extensively affective prosody such as stress, vowel lengthening and intonation contours. Children of 7-8-years, however, had very little affective prosody in their stories. Even though their stories were otherwise more coherent and complete than those produced by the 3-4-year-olds, the narratives were affectively quite bland. In the younger group the use of paralinguistic means reflected mainly the child's own excitement at the events in their story, whereas older children were not so enthusiastic about the story. Reilly found, however, that 7-8-year-olds do not yet use paralinguistic devices consciously and deliberately as adults do to make a story interesting and exciting to the listener. Thus what are apparently 
the same means are used differently and in different functions in the course of development.

Reilly (2001) has also investigated differences between spoken and signed language in terms of evaluative expressions. In this respect paralinguistic devices are interesting, since they function both as grammatical and evaluative elements in sign languages (Reilly 2000). Since sign languages are multi-channelled by nature there are several potential means of conveying paralinguistic information: modification of sign speed and movement, facial expressions (which can be linguistic elements as well) and gestures (Reilly 2001). Finnish Sign Language, like sign languages generally, conveys phonological, morphological, syntactic and textual information also non-manually, i.e., by movements of the mouth, head and body, and with facial expressions (see Takkinen 2008). For example, questions are expressed by raising or lowering eyebrows, and adverbial information is expressed by mouth movements and/or widening or squinting the eyes as well as by modifying the extent or speed of the articulation movement in signs. On the other hand, lexical meanings are produced by manual lexicalised signs. Gestures although produced by the hands - do not have lexicalised form or meaning.

Reilly (2001) found that both deaf and hearing adults use evaluative expressions in similar phases of a story: just before a conflict and at its resolution. However, the means of doing this were different in each case. The hearing adults used lexical devices whereas the deaf adults preferred paralinguistic ones. However, deaf children followed a similar developmental path to hearing children: pre-school-age children made extensive use of paralinguistic devices but already at 5 years of age the use of lexical expressions had increased significantly. The use of paralinguistic devices continued to decrease and by the age of seven the signed stories were as bland as the stories told by hearing children of the same age. It seems that the possibilities provided by a signed language or the example set by deaf adults do not encourage deaf children to maintain the use of paralinguistic devices in their narratives, but at a later stage they may notice for themselves that a story becomes more interesting and more lively - a better narrative - with paralinguistic means. 


\section{Data and methods}

Our subject is an 11-year-old boy, Jimmy, who was born deaf in a hearing Finnish family. His parents learnt Finnish Sign Language (FinSL) and they used FinSL with Jimmy before he got a cochlear implant ${ }^{1}$ (CI, an electronic hearing device) a little before his fifth birthday. Thus, Jimmy's first language is FinSL. After the implant he has acquired Finnish and has become bilingual. His language development has been followed since 2005 . Jimmy goes to a school for hearing children, where he is taught in Finnish. At home he uses FinSL in some situations when it is impossible to use CI, such as while swimming, in sauna, or when the distance between interlocutors is too far to use speech. FinSL is also used during family courses in a programme organized for deaf and hard of hearing children by The Service Foundation for the Deaf. The purpose of this Junior Program project is to teach FinSL to hearing parents and organise activities for deaf children and their hearing siblings. All the activities are arranged by deaf signing adults to ensure sign language immersion during three weekend courses and one one-week course provided every year in the programme.

A cochlear implant is an electronic hearing device which has given good results in hearing. Many deaf and severely hard of hearing children have been able to acquire a spoken language by hearing better than earlier with the use of acoustic hearing aids. Many hearing parents decide to use sign language with their deaf or hard of hearing children to ensure early language development: they also want to have sign language as a communication resource for their child even if spoken language might develop well later and become the dominant language for their child. On the other hand there are also many hearing parents who do not use sign language but rely entirely on the cochlear implant, with

\footnotetext{
${ }^{1}$ A cochlear implant is a device that provides direct electrical stimulation to the auditory nerve. In sensorineural hearing loss where there is damage to the tiny hair cells in the cochlea, sound cannot reach the auditory nerve. With a cochlear implant, the damaged hair cells are bypassed and the auditory nerve is stimulated directly. The cochlear implant does not result in "restored" or "cured" hearing. It does, however, allow for the perception of sound "sensation". Cochlear implants have external (outside) parts and internal (surgically implanted) parts. http://www.asha.org/public/hearing/treatment/cochlear_implant.htm (accessed May 15, 2010)
} 
which they hope spoken language acquisition will go well. However, the cochlear implant does not function ideally for every user (Lonka and Hasan 2006, Lonka et al. 2011). Jimmy started learning sign language at the age of three, and was already able to express himself with multi-sign utterances before he got his CI.

The data consist of two frog stories (Meyer 1969) told by Jimmy. One of the stories is in Finnish and the other one in FinSL. The signed story was collected during a conversation with a deaf adult, and the Finnish story in a spoken conversation with a Finnish-speaking adult. Both narratives were videotaped, and the duration of the spoken story was 5 minutes 46 seconds and of the signed story 5 minutes 15 seconds. The signed story was transcribed in ELAN format (EUDICO Linguistic Annotator) ${ }^{2}$ and the spoken story in CHILDES format (MacWhinney 2000). The ELAN format for sign language also includes the original video recording connected to the transcript. "The Frog Story" is a picture book without words about a boy, a dog and a frog. The frog escapes one night from the boy's room. When the boy and the dog wake up the next morning they discover that the jar where they kept the frog is empty and they realise that the frog has gone away. The boy and the dog start searching for the frog, and during the search they find a beehive and a swarm of bees, a mole, an owl and a moose before they finally find the frog and its family. In the end the boy and the dog return home with the frog.

The evaluation devices used in Jimmy's frog stories in Finnish and FinSL were analysed both qualitatively and quantitatively. The qualitative analysis was made on the basis of Reilly's (1992, 2001: 405-406) classification:

1. Characterisation or quoted speech

- speaking for one of the characters

2. Evaluative comments

- inferring the emotions of the characters, using labels for emotional states and behaviours

- evaluation of an action

- evaluation of a character

- inferring cognitive processes of the characters, using mental verbs

${ }^{2}$ ELAN (EUDICO Linguistic Annotator) is a multimedia annotation tool developed at the Max Planck Institute for Psycholinguistics. 
3. Facial expressions

4. Gestures

- only those related to a particular utterance

5. Prosodic features

- pitch, length, volume, voice quality

- lexical/phonological stress

Although for example quoting speech and making evaluative comments are basically lexical strategies and facial expressions, gestures and prosodic features are paralinguistic, the distinction between the two is not always easy or even reasonable to make because in many cases they occur together. A typical example of their co-occurrence is when the narrator simultaneously changes his voice, quotes the character's speech, uses facial expressions and gestures typical of the character and so forth. Also evaluations of cognitive processes or emotional states can be included in this kind of role shifting: anger, happiness and sadness, among other feelings, could be shown in the way a character speaks. Thus lexical and paralinguistic expressions are not independent of each other, but rather they are often tied together in the same utterance.

\section{Results}

\subsection{Evaluative expressions in the Finnish frog story}

In the Finnish version of the frog story Jimmy concentrated on lexical expressions of evaluation. There is a total of 45 occurrences of some kind of evaluation in Jimmy's spoken story (Figure 1). More than one third of them (16 occurrences) are evaluative comments on an activity or a character, mostly the former:

1) sammakko yrittää \# ss salata tota hiipiä tota ulos 'the frog tries \# to sneak out on the quiet'

2) sattui ku myyrä puras sitä nenää 'it hurt when a mole bit him on the nose' 
In Example 1 the evaluation concerns the mode of the frog's movements when it escapes from the glass jar in the boy's room. The picture in the book shows only the frog getting out of the jar while the boy and the dog are asleep. Thus the sneaking and doing it undercover are something that the narrator has to infer or imagine happening. At the same time this gives the reason why the story is worth telling: after someone has escaped usually others start searching for them sooner or later. Example 2 comments on an activity in two ways: first, what the mole did (it bit the boy on the nose), and then what the action caused (pain) or how the boy experienced the mole's act (he was hurt). Again, the pictures do not show the action at all and thus this is something the narrator has interpreted based on two consecutive pictures in the book. This is also an example of the use of causal connectors, which are considered by Bamberg and Damrad-Frye (1991: 692) to be one way to express evaluation. In Example $2 \mathrm{ku}(\mathrm{n})$ 'when' expresses a causal relationship between the main clause (sattui 'it hurt') and the subordinate clause (Iso suomen kielioppi 2004: 779).

Most of the evaluative comments expressed by Jimmy are similar to those presented above. However, there are also comments that concern the whole event or scene as well as interpretations of the characters' communication:

3) Ja poika avasi ikkuna. Jo oli olipas hyvä ilma. 'And the boy opened the window. What a nice morning it was already.'

4) onneks ei ollu paha. 'Luckily it wasn't bad'.

5) koira sano sille ampiaispesälle et se luuli et siel on sammakko ni sano hauu 'the dog said to the beehive that it thought that the frog was there and therefore it said woof woof'

In Example 3 the narrator comments on the weather. The picture, however, shows only a window and a wall, the boy looking out of the window and the dog falling or jumping out of the window with the jar on his head. Nothing in the picture refers to good weather. It is the narrator's interpretation which serves as a global comment on the whole story. Example 4 is a comment on the outcome of an event, that is, when the dog either jumps or falls out of the window with a glass jar on his head. The jar breaks but the dog is not hurt. Example 5 differs from all the other comments in that it is an interpretation from "dogs' language" 
into the narrator's language. While it is an interpretation of the barking it is also an explanation of why the dog is barking at the beehive in the first place.

In Jimmy's Finnish frog story 14 evaluative expressions out of the total of 45 (approximately one third of all occurrences) are either characterisation of a character or quoting their speech. As Examples 6 and 7 show, the quotations (or sounds of the dog or the owl) are usually preceded by a reporting clause:

6) ja poika sano \# sammakko missä oleet. 'and the boy said \# frog where are you'.

7) ja pöllö sano huhuu sitte toi vörk\& \# poika sano että lopeta. 'and then the owl said tu-whit tu-whoo then the vörk\& \# boy said stop'.

Thus, usually Jimmy keeps the narrator's role at least partially, even though he quotes what people say quite frequently and the quotes are said in a different voice than the other parts of the story. In fact, no thorough role shift occurs in Jimmy's story. It is also worth noticing that these prosodic features in connection to quoted speech are the only occurrences of paralinguistic devices in Jimmy's Finnish frog story.

Commenting on an activity or character and quoting characters' speech thus cover two thirds of all the occurrences of evaluative expressions in Jimmy's Finnish frog story. The remaining one third of the occurrences include comments on mental processes (6 occurrences), comments on feelings ( 1 occurrence) and prosodic features together with a verbal expression (8 occurrences). Verbal comments on mental processes and feelings are reflections of the interpretations that the narrator makes of the actions or facial expressions, for example, shown in the pictures. A successful interpretation of these internal processes of the characters requires theory of mind abilities i.e. the ability to think oneself into other people's minds. However, this is not enough, since a narrator should also realise the importance and function of this kind of comment in the course of a narrative.

8) poika oli vähä vihanen, kun tuo lasipurkki meni rikki. 'the boy was a bit angry when the jar got broken'.

9) poika kuuli myös 'the boy heard also'

10) sitte koira huomas 'then the dog noticed' 
The only comment on emotions in Jimmy's Finnish frog story is presented in Example 8. It is also an example of connecting cause (broken jar) and effect (anger), as in Example 2. The mental processes in Jimmy's narrative are usually seeing and hearing (Example 9), but sometimes the boy or the dog does notice something (Example 10) or wonder about something. On the whole, however, the inner life of the characters gets very little attention in Jimmy's story.

The examples of evaluative expressions discussed so far have been entirely or almost entirely verbal expressions. The only paralinguistic features ( 8 occurrences) came up in connection with quoted speech, where the change of voice quality implied a partial shift to a character's role. Otherwise Jimmy's story was bland and monotonic, like the stories told by 7-8-year-olds in Reilly's (1992) study. This does not necessarily mean that Jimmy does not know how to use paralinguistic devices. If he had been asked to tell the frog story to a little child, he might have used more of them, such as gestures, facial expressions and prosody, to create a good, interesting story which could capture and keep a child's attention. This at least was the case in Reilly's study (1992).

\subsection{Evaluation in FinSL}

When telling the frog story in Finnish sign language Jimmy used both lexical and paralinguistic expressions (Figure 1). His story included altogether 58 examples of evaluative expressions, of which $33(57 \%)$ were lexical and $25(43 \%)$ paralinguistic.

Describing the characters and quoting their speech was used ten times. Jimmy characterized how the boy called the frog (MISSÄ OLLA SAMMAKKO OLLA ${ }^{3}$, where be frog be), and how he fell backwards (POIKA KAATUA-SELÄLLEEN). Twice he took the role of the dog, once to show that it was barking (KOIRA HAUKKUA-woof-woof-woof), and another time showing that it was creeping along quietly (KOIRA MENNÄ HIIPIÄ, dog go creep). Jimmy also took the roles of other animals in the story, characterizing that the frog was croaking (SAMMAKKO K-R-U-K-S KURNUTTAA, frog K-R-U-K-S croak), that a moose bent its head down (HIRVI PAINAA-PÄÄ-ALAS, moose bent head down), and how an owl was flying (PÖLLÖ

${ }^{3}$ Words written in upper-case refer to manual signs produced by the child. 
LENTÄÄ-SIIVET-LÄISKYEN, owl flying with large wings). All of these occurrences demand imagination and evaluation of the action because they are not seen explicitly in the pictures.

Jimmy used 23 evaluative comments on the characters, their feelings and activities. In his comments he also used mental verbs. Examples of his evaluation of feeling are POIKA SÄIKÄHTÄ̈̈, PELÄSTYÄ (boy get frightened) and SE OLLA VIHAINEN (he be angry), where he evaluates the feelings of the boy.

Jimmy also evaluated actions or characters in the story (15). He described how the frog creeps secretly out of the room when the boy is asleep (SAMMAKKO HIIPIÄ SALAA, frog creep secretly). In other examples he evaluated how loudly the boy cries when calling the frog (SE HUUTAA TOSI KOVAA, it shout very loudly), and that the boy looks for the frog in the forest (POIKA ETSIÄ, boy search). Jimmy also reported that the swarm of wasps attacks the boy (AMPIASPARVI MENNÄ KIMPPUUN, swarm of wasps attack), and how the boy looks at something over a fallen tree SE KURKISTAA (it peep over tree). All these evaluations demanded imaginative extension of the action beyond what the pictures revealed.

In his sign language story Jimmy also used mental verbs (5 expressions) when evaluating the characters' actions. He said that the mother wondered about something and then told the boy to go to bed (ÄITI IHMETELLÄ, mother wonder) and that the boy wondered about something when he noticed that the frog had disappeared (POIKA IHMETELLÄ, boy wonder). He also reported that the dog heard the frog croaking (KOIRA KUULLA, dog hear) and that both the boy and the dog were surprised when they noticed so many frogs (POIKA KOIRA HÄMMÄSTYÄ boy dog be surprised).

In addition to lexical means, Jimmy used paralinguistic means to convey his evaluations. Almost half of Jimmy's evaluative expressions were paralinguistic (25/58). He used facial expressions along with lexical expressions ten times when saying that the boy wondered about something, once where the frog had gone and then that the moose picked up the boy with its antlers (POIKA ... IHMETELLÄ ${ }^{4}$ boy wonder). Jimmy also evaluated the action with his facial expression when he reported that the boy got frightened when the dog fell out of the window (POIKA S̈̈IKÄHTÄÄ boy get-frightened), when he said that suddenly the boy was on the ant-

\footnotetext{
${ }^{4}$ The line under the words refers to the scope of the paralinguistic device in question.
} 
lers of the moose (TAPAHTUA-YHTÄKKIÄ happen-suddenly), and that the boy was trying hard not to fall off (POIKA- KAATUA-TAAKSEPÄIN- PYRISTELLÄ boy-fall-backwards-fight). In sign languages it is typical to use facial expressions combined with verbal ones when talking about actions which involve stronger feelings, e.g. getting frightened or surprised.

Jimmy often used facial expressions in his story. He used them to communicate that the boy heard something from the water (VESI VESI KUULLA water water hear) and then that it was a frog that was croaking (SAMMAKKO KURNUTTAA frog croak). Then he reported that the boy saw fallen trees and that he peeped over them (POIKA...PUU-POIKITTAIN YLI KURKISTAA boy... tree-horizontally over peep) and how he and the dog were surprised to see so many frogs behind the tree (POIKA KOIRA IHME boy dog wonder).

One form of paralinguistic expression is gestures, which are used alone or with words or signs. Jimmy used gestures six times in his story. He used them when he said that the dog licked the boy's face (KOIRA NUOLAISTA dog lick). He also used gestures when saying that the moose bent down and that the boy struggled when he fell into the water (HIRVITAIVUTTAA-PÄ̈̈TÄ-ALAS moose-bend-head-down $\ldots$ POIKA- KAATUA-TAAKSEPÄIN- PYRISTELLÄ boy-fallbackwards-fight). Jimmy used gestures when reporting how the frog croaked (SAMMAKKO KURNUTTAA frog croak), and how the boy asked the dog to be quiet when he was listening to the croaking (KOIRA $\underline{\mathrm{SHHHH}} \operatorname{dog} \underline{\operatorname{shhh}}$ ). When the boy left the pond with the dog and the frog he said good-bye and Jimmy waved his hand (HEI-HEI bye-bye).

Prosodic features were often accompanied in the signs by gestures or facial expressions. Prosodic features were also manifested by modifying the movement of a sign by slowing it down, prolonging it, or speeding it up and strengthening it. When expressing that the frog crept secretly away (SAMMAKKO HIIPIÄ frog creep), or that the boy was peeping over a tree (POIKA...PUU-POIKITTAIN YLI KURKISTAA boy ... tree-horizontally over peep) Jimmy used a slow prolonged movement. On the other hand, when he was narrating that something happened quickly (TAPAHTUA-YHTÄKKIÄ happen-suddenly), or that the boy got frightened (POIKA SÄIKÄHTÄ̈̈ boy get-frightened) he used a fast movement. He used a prolonged strong movement when saying that the dog was barking (KOIRA 
HAUKKUA dog bark), and that an owl was flying on its large strong wings (PÖLLÖ LENTÄÄ-SIIVET-LÄISKYEN, owl flying with large wings). The modification of the signed movements reflects Jimmy's imagining of how the actions were done or how they happened.

Lexical stress was used once. Jimmy said that the boy shouted very loudly "Frog, where are you?" SE HUUTAA TOSI KOVASTI (it shout very loudly). The movement of the sign TOSI (very) was strong and prolonged, which strengthened its meaning. The stress was on a sign which does not express any action. In that way it differed from the previous examples, where the modification of a movement occurred in the action sign.

\section{Conclusion}

The comparison of the evaluative expressions which Jimmy used in these two versions of the frog story shows that he concentrated on lexical expressions of evaluation in the Finnish story and that in FinSL he used in a more balanced way both lexical and paralinguistic expressions. Figure 1 shows the distribution of the use of the different means in the Finnish and FinSL stories.

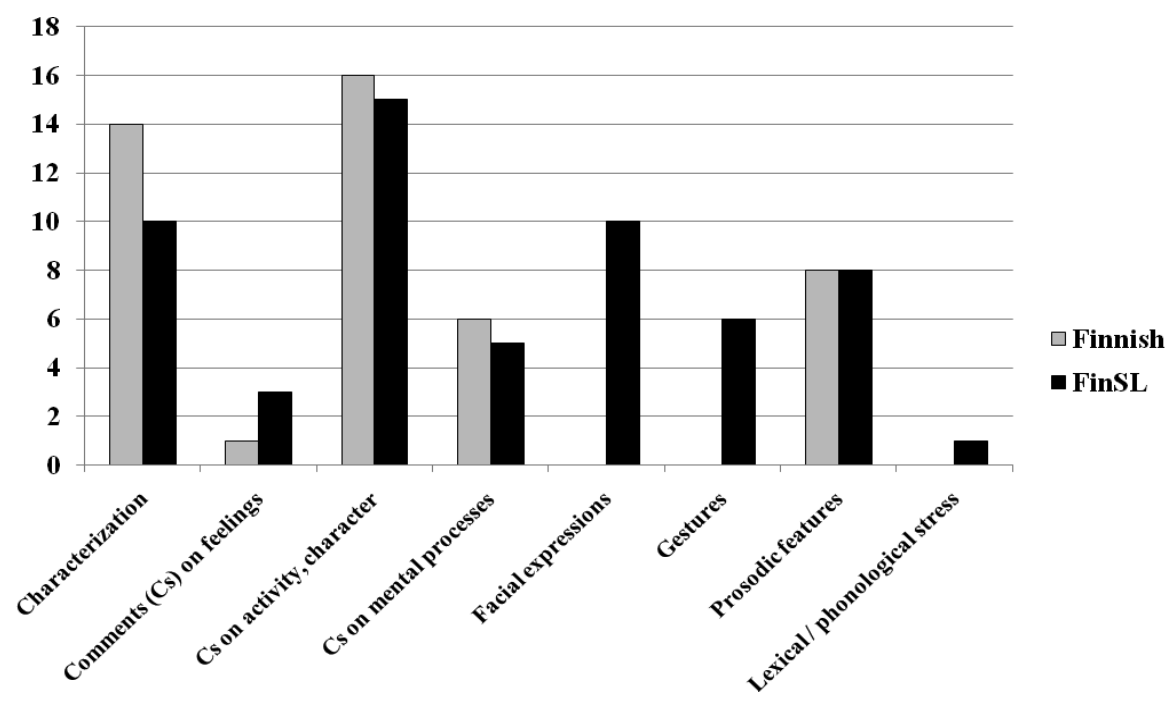

Figure 1. Distribution of the different evaluation device in the Finnish and FinSL stories. 
The most common way of expressing evaluation in both the Finnish and the FinSL frog story was to make evaluative comments on the characters and their activities. Characterization or quoting what a character had said was the second most usual means in both stories. The use of evaluative comments on feelings and the use of mental verbs were also very similar in both versions. The main difference in the use of evaluating expressions in telling the two stories was in the use of paralinguistic means. In the FinSL story Jimmy used a lot of facial expressions in a paralinguistic way (e.g. expressing surprise or fright) whereas in the Finnish story he did not use them at all. Similarly, Jimmy used gestures several times in the FinSL story but not in the Finnish version. However, he used prosodic features equally frequently, although qualitatively their use differed a lot: in the Finnish story changes of voice quality marked a partial role shift whereas in the FinSL version prosodic features were used in connection to many kinds of action. Lexical stress was used only once in the FinSL story and not at all in the Finnish story. The total number of different evaluative devices used by Jimmy was $22.4 \%$ higher in FinSL than in Finnish. The use of lexical means was a little higher (10.8\%) in Finnish story than in the FinSL one, while the use of paralinguistic means was $68 \%$ higher in the FinSL than in the Finnish story.

The results from the FinSL story are in accordance with Reilly's (1992) results concerning 10-11-year-olds when they were asked to tell a good story to a younger child. In Reilly's study these children used paralinguistic devices in order to make the story more interesting to the young audience. However, in the Finnish story lexical devices dominated, as they dominated also in 7-8-year-olds' stories in Reilly's research. On the other hand, there may be other factors apart from the different languages that affected Jimmy's different use of evaluative devices in his two versions of the story. For instance, Jimmy began to acquire FinSL as his first language at the age of three, when he started to get sign language input. He had used multiple-sign utterances in FinSL before he got his CI, and only after that did he gradually begin to acquire spoken Finnish. This order of acquisition might be one reason for the richer use of evaluation devices in the FinSL story. On the other hand one might have assumed that there would be some transfer of paralinguistic means from sign language to spoken language. However, in his Finnish story Jim- 
my used very few paralinguistic devices, in fact only prosodic features which co-occurred with taking a character's role. There could also be some effects from using a hearing aid, in this case a CI, which does not, according to several studies (e.g. Fandén, McTaggart and Hellstadius 2008, Most and Aviner 2009 and Torppa et al. 2010), adequately support the normal perception of different kinds of prosodic information of speech. Because of this a CI user may concentrate too much on lexical units when acquiring Finnish, for example. Another reason for the lack of other paralinguistic features (gestures and facial expressions) could be that Jimmy separates the two languages very strictly: only vocal prosody belongs to a spoken language, while gestures and facial expressions belong to signed languages. Culture could also have an effect: Finnish-speaking people generally do not use many gestures or facial expressions in their communication, whereas in signing it is an essential part of communication.

To be able to get a wider picture of the use of evaluative expressions in bimodal bilingual users of a CI, data from a larger number of informants should be analysed. Getting comparative data from monolingual users of FinSL and Finnish as well as from normally hearing bimodal bilingual FinSL and Finnish users would also be very important. Such information would give us a clearer picture of the evaluative expressions preferred in narration by sign language and Finnish language users of different ages.

\section{Addresses:}

Lea Nieminen

Centre for Applied Language Studies

P.O.Box 35

FIN-40014 University of Jyväskylä

Finland

E-mail: lea.s.m.nieminen@jyu.fi

Ritva Takkinen

Department of Languages (F)/Sign Language Centre

P.O.Box 35

FIN-40014 University of Jyväskylä

Finland

E-mail: ritva.takkinen@jyu.fi 


\section{References}

Bamberg, Michael and Robin Damrad-Frye (1991) "On the ability to provide evaluative comments: further explorations of children's narrative competencies". Journal of Child Language 18, 3, 689-710.

Berman, Ruth A. (2001) "Narrative development in multilingual contexts". In Ludo Verhoeven and Sven Strömqvist, eds. Narrative development in a multilingual context, 419-428. Philadelphia, PA: John Benjamins.

Eaton, Judy H., Glyn M. Collis and Vicky A. Lewis (1999) "Evaluative explanations in children's narratives of a video sequence without dialogue". Journal of Child Language 26, 3, 699-720.

Fandén, Anna, Julia McTaggart and Åsa Hellstadius (2008) Prosodisk förmåga hos svenska grundskolebarn med cochleaimplantat. Unpublished Master's thesis. Lindköping: Lindköpings universitet. Institutionen för klinisk och experimentell medicin, Logopedprogrammet.

Cochlear Implants. <http://www.asha.org/public/hearing/treatment/cochlear_ implant.htm>. Accessed May 15, 2010.

Gutiérrez-Clellen, Vera (2002) "Narratives in two languages: assessing performance of bilingual children". Linguistics and Education 13, 2, 175-197.

Iso suomen kielioppi. Auli Hakulinen, Maria Vilkuna, Riitta Korhonen, Vesa Koivisto, Tarja Riitta Heinonen, and Irja Alho, eds. Helsinki: Suomalaisen Kirjallisuuden Seura, 2004.

Küntay, Aylin C. and Nakamura, Keiko (2004) "Linguistic strategies serving evaluative functions: a comparison between Japanese and Turkish narratives". In Sven Strömqvist and Ludo Verhoeven, eds. Relating events in narrative, vol. 2. Typological and contextual perspectives, 329-358. Mahwah, NJ: Lawrence Erlbaum Associates.

Labov, William and Joshua Waletzky (1967) "Narrative analysis: oral versions of personal experience". In June Helm, ed. Essays on the verbal and visual arts, 12-44. Seattle: University of Washington Press.

Lonka, Eila and Marja Hasan (2006) "Sisäkorvaistutetta käyttävien lasten kommunikaatio-, koulu- ja päivähoitotilanne Suomessa". In Eeva Lehto, Marja Hasan, and Ritva Parkas, eds. Satakieliseminaari 2006. Helsinki: Satakieliohjelma.

Lonka, Eila, Marja Hasan, and Erkki Komulainen (2011) "Spoken language skills and educational placement in Finnish children with cochlear implants". Folia Phoniatrica et Logopaedica 63, 6, 296-304.

MacWhinney, Brian (2000). The CHILDES project: Tools for analyzing talk. 3rd ed. Mahwah, NJ: Lawrence Erlbaum Associates.

Meyer, Mercer (1969) Frog, where are you? New York: Dial Press. 
Most, Tova and Chen Aviner (2009) “Auditory, visual, and auditory-visual perception of emotions by individuals with cochlear implants, hearing aids, and normal hearing". Journal of Deaf Studies and Deaf Education $14,4,449-464$.

Reilly, Judy (1992) "How to tell a good story: the intersection of language and affect in children's narratives". Journal of Narrative and Life History 2, 4, 355-377.

Reilly, Jydy (2000) "Bringing affective expression into the service of language: acquiring perspective marking in narratives". In Karen Emmoray and Harlan Lane, eds. The signs of language revisited: an anthology in honor of Ursula Belugi and Edward Klima, 415-432. Mahwah, NJ: Lawrence Erlbaum Associates.

Reilly, Judy (2001) "From affect to language". In Ludo Verhoeven and Sven Strömqvist, eds. Narrative development in a multilingual context, 399417. Philadelphia, PA: John Benjamins.

Shiro, Martha (2003) "Genre and evaluation in narrative development”. Journal of Child Language 30, 2, 165-195.

Slobin, Dan Isaac (1985) "Crosslinguistic evidence of the language-making capacity”. In Dan Isaac Slobin, ed. The crosslinguistic study of language acquisition, vol. 2, 1157-1256. New Jersey: Lawrence Erlbaum Associates.

Speece, Deborah L., Froma P. Roth, David H. Cooper, and Susan De La Paz (1999) "The relevance of oral language skills to early literacy: a multivariate analysis". Applied Psycholinguistics 20, 2, 167-190.

Strömqvist, Sven and Ludo Verhoeven (2004) "Typological and contextual perspectives on narrative development". In Sven Strömqvist and Ludo Verhoeven, eds. Relating events in narrative. Vol. 2. Typological and contextual perspectives, 3-14. Mahwah, NJ: Lawrence Erlbaum Associates.

Tager-Flusberg, Helen and Kate Sullivan (1995) “Attributing mental states to story characters: a comparison of narratives produced by autistic and mentally retarded individuals". Applied Psycholinguistics 16, 241256.

Takkinen, Ritva (2008) "The acquisition of Finnish Sign Language". In Anu Klippi and Kaisa Launonen, eds. Research in logopedics. Speech and language therapy in Finland, 175-205. Clevedon: Multilingual Matters.

Torppa, Ritva, Andrew Faulkner, Juhani Järvikivi, and Martti Vainio (2010) "Acquisition of focus by normal hearing and cochlear implanted children: the role of musical experience." In Proceedings of the 5th International Conference of Speech Prosody. Internet publication. $<$ http://speechprosody2010.illinois.edu/papers/100977.pdf > . Accessed June 23, 2010. 
Verhoeven, Ludo (2004) "Bilingualism and narrative construction". In Sven Strömqvist and Ludo Verhoeven, eds. Relating events in narrative. Vol. 2. Typological and contextual perspectives, 435-454. Mahwah, NJ: Lawrence Erlbaum Associates.

Kokkuvõte. Lea Nieminen ja Ritva Takkinen: Hinnanguid väljendav keel kurdi sisekõrva implantaadiga lapse räägitud ja viibatud lugudes: sõnad, märgid või paralingvistilised väljendid? Artiklis analüüsitakse kakskeelse lapse hinnanguid väljendava keele kasutust ja kvaliteeti jutustamissituatsioonis. Uuritav, 11-aastane soome poiss Jimmy on kakskeelne ning oskab soome viipekeelt ja kõnekeelt. Ta sündis kurdina, kuid sai viieaastaselt sisekõrva (kohlea) implantaadi (kuulmisimplantaat). Andmed pärinevad räägitud ja viipekeelse jutustuse „Lugu konnast” versioonist. Analüüs näitab, et laps kasutab räägitud ja viibatud lugudes erinevad hinnanguid väljendavaid vahendeid ja väljendeid. Soome keeles räägitud loos kasutas ta enamasti sõnavaravahendeid: märkusi tegelase ja tema tegevuse kohta ning otsest kõnet, kombineerides seda mõnikord prosoodiliste võtetega. Soome viipekeeles jutustatud loos kasutas ta tasakaalustatult nii sõnavara- kui ka paralingvistilisi vahendeid.

Võtmesõnad: jutustamine, hinnanguid väljendav keel, keele areng, kakskeelsuse omandamine, bimodaalne kakskeelsuse omandamine, soome viipekeel 